\title{
DUMÉZIL REVURDERET
}

\author{
Bent Bjerring-Nielsen
}

\section{Indledning}

Georges Dumézil fylder meget i den religionsvidenskabelige forskning. Hans ambition var at dække hele det indoeuropæiske felt, og på dette område anses hans teorier af mange for uomgængelige, hvad der f.eks. kan illustreres i forhold til nordisk religion. Hans Jørgen Lundager Jensen og Jens Peter Schjødt understreger således i deres glimrende - og særdeles positive - introduktion til Dumézil, Suverceniteten, kampen og frugtbarheden, at "det ... ikke kan lade sig gøre at arbejde med nordisk eller keltisk mytologi uden at tage stilling til Dumézils undersøgelser” (Jensen \& Schjødt 1994, 197). Et andet eksempel kan være Britt-Mari Näsströms introduktion til nordisk religion, Forn-skandinavisk religion. I denne bog ses den dumézilske påvirkning ikke først og fremmest i de eksplicitte henvisninger til hans teorier, selv om sådanne forekommer, men snarere i selve arbejdsmåden. Når Näsström f.eks. behandler forholdet mellem Aser og Vaner er indfaldsvinklen, at "[m]an kan förklara konflikten genom att jämföre dem med andra, tidiga, berättelser inom den indoeuropeiske mytskatten" (Näsström 2002, 49). I forlængelse af denne bemærkning inddrager hun så romersk og keltisk mytologi på en måde, som tydeligt indskriver hende i et dumézilsk paradigme.

Eksemplerne er hentet fra nordisk religion, men kunne i princippet være hentet fra mange andre felter inden for den indoeuropæiske mytologi. Det må derfor være nok så relevant at diskutere selve det teoretiske grundlag for Dumézil og herunder særligt påstanden om, at han har beskrevet en unik indoeuropæisk bevidsthedsform; denne forestilling vil jeg problematisere med udgangspunkt $i$ et tidligere - og delvis mislykket - forsøg på det samme af John Brough. Udgangspunktet vil dog være en kort introduktion til Dumézil.

\section{Dumézils hovedtese}

Georges Dumézils særdeles omfattende forfatterskab kan ses som et tema med variationer. Hovedtemaet, som gennemspilles i særdeles mange variationer, er påstanden om, at der eksisterer et strukturelt fællestræk ved indoeuropæisk tænkning generelt. Dette strukturelle fællestræk i tænkningen, som Dumézil med et ikke alt for velvalgt ord foretrækker at kalde ideologi, er tendensen til at tænke $\mathrm{i}$ en tredeling. Ved denne tredeling sker der en opsplitning mellem tre funktioner: magtens, krigens og forplantningens funktion (bredt defineret), mellem suveræniteten, kampen og frugtbarheden. 
Et eksempel på en sådan tredeling kan være den såkaldte præ-kapitolinske romerske gudetriade Jupiter, Mars og Quirinius, som Dumézil forbinder med hver af de respektive funktioner. ${ }^{1}$

Af disse funktioner er de to første, magts - eller suverænitetsfunktionen - og krigsfunktionen klarere defineret end den tredje. Førstefunktionen har at gøre med magt og suverænitet $\mathrm{i}$ både sakral og juridisk forstand, mens andenfunktionen dækker feltet af fysisk styrke, vold og krig. Frugtbarhedsfunktionen dækker derimod et bredere felt af rigdom, sundhed, seksualitet, vellyst, forplantning, føde og fred; det drejer sig altså her om frugtbarhed i en meget bred forstand.

Som udgangspunkt mente Dumézil, at tredelingen afspejlede en social kendsgerning i de tidlige indoeuropæiske samfund. I erkendelse af, at dette reelt kun kunne konstateres for det indiske samfunds vedkommende (med dets opdeling i brahmaner, præster; ksatriyaer, krigere og vaisyaer, agerbrugere, håndværkere og handelsmænd) forkastede Dumézil ad åre denne forestilling; i Dumézils senere forfatterskab ses tredelingen således (bortset fra i Indien) som en bevidsthedsmæssig og ikke en social kendsgerning. Dette sammenfatter han i Mythe et Épopée I på følgende måde:

... et afgørende fremskridt fandt sted den dag, jeg erkendte, henimod 1950, at den 'tredelte ideologi' ikke nødvendigvis følger den indiske model i et samfunds liv; at den tværtimod, der hvor man konstaterede den, kunne være (ikke længere være, aldrig have været) intet andet end et ideal, og samtidig et middel til at analysere og fortolke de kræfter, som sikrer verdens gang og menneskenes liv. (Dumézil 1974, 15)

Dumézil opererer i øvrigt ikke kun med tredelinger, men mener også at kunne finde binære strukturer inden for de tre funktioner. Det er ikke særligt overraskende, da binære opdelinger sandsynligvis er de mest udbredte overhovedet; ud fra en strikt strukturalistisk indfaldsvinkel ville man sige, at de var konstituerende for betydningsdannelsen som sådan. Dumézil finder særligt de binære opdelinger inden for den første funktion, suverænitetsfunktionen, som typisk opdeles i to aspekter. Dette blev først klart udviklet i forbindelse med den vediske mytologi, hvor Dumézil ser suverænitetsfunktionen udøvet af to guder, Mitra og Varuna, der varetager hver sit aspekt af denne funktion. Medens Mitra repræsenterer de rationelle og juridiske aspekter, repræsenterer Varuna de irrationelle og magiske; Mitra repræsenterer ordenen og er som sådan mere forudsigelig og omgængelig end Varuna, der er tættere forbundet med kaos og vold. I Les Dieux des Germain sammenfatter Dumézil en gennemgang af dette forhold i formlen: "Mitra 'Herskerguden som jurist', Varuna 'Herskerguden som magiker'" (1959a, 61). De varetager begge suverænitetsfunktionen, men Mitra repræsenterer det juridiske aspekt, hvor Varuna repræsenterer det magiske aspekt. I den nordiske mytologi repræsenteres de to aspekter af suverænitetsfunktionen af henholdsvis Tyr og Odin.

\footnotetext{
${ }^{1}$ Dumezil har behandlet den romerske mytologi i en lang række værker; et af dem har navn efter den anførte gudetriade, jf. Dumézil 1941.
} 
Dumézil ser f.eks. det ovennævnte skema demonstreret i forbindelse med Roms fire første, mytologiske konger: Romulus, Numa Pompilius, Tullus Hostilius og Ancus Marcius. Romulus tilskrives her førstefunktionens andet aspekt og Numa Pompilius førstefunktionens første aspekt, mens Tullus Hostilius og Ancus Marius forbindes med henholdsvis andenfunktionen og tredjefunktionen. ${ }^{2}$

De binære kategoriseringer optræder også på en lang række andre områder; det er f.eks. tilfældet med den nordiske mytologi i forholdet mellem de to gudegrupperinger, Aser og Vaner. I Du Mythe au Roman sammenfatter Dumézil på et tidspunkt dette forhold ved at påpege, at der mellem Aser og Vaner er en forskel i såvel funktion som rang. De første tager sig af de kongelige, magiske, juridiske og krigeriske funktioner, mens de andre tager sig af rigdommen, frugtbarheden og vellysten. I en hierarkisk forståelse vil Vanernes frugtbarhedsfunktion derfor være underordnet den høje magi og den krigeriske kraft, skriver Dumézil (1970, 84f).

\section{Teoretiske forudsætninger}

Meget generelt kan man sige, at Dumézils arbejde med det indoeuropæiske ligger inden for et 1700-tals herdersk paradigme, hvor sandheden om en ting søges gennem dens historiske oprindelse. Inden for indoeuropæistikken har det ført til mange overvejelser over det proto-indoeuropæiske folk og sprog, hvor selve mangfoldigheden af uforenelige teorier synes at vise det meningsløse i projektet (jf. f.eks. Jensen \& Schjødt 1994, $28 \mathrm{ff}$ og Littleton 1982, 23ff).

Mere specifikt er Dumézils forudsætning den diakrone sprogvidenskab, som har tildelt begrebet 'indoeuropæisk' en særlig mening ved at påpege eksistensen af et indoeuropæisk sprogfællesskab. Imellem (blandt andre) slaviske, romanske, germanske, keltiske, indiske og iranske sprog er der strukturelle ligheder, som medfører en blandt sprogvidenskabsfolk generelt accepteret opfattelse af dem som en sammenhængende sprogæt (jf. Jensen \& Schjødt 1994, 17ff). Dumézils grundlæggende tese i forhold til dette er, at det indoeuropæiske sprogfællesskab også er et bevidsthedsmæssigt (eller ideologisk, som han foretrækker at kalde det) fællesskab, som lader sig beskrive i et forholdsvis begrænset antal funktioner.

Dette sidste, reduktionen af det ideologiske fællesskab til et begrænset antal funktioner, udtrykker en mere omdiskuteret side af den dumézilske teoridannelse, nemlig forholdet til strukturalismen. Der er mange forskellige bud på, i hvor høj grad den dumézilske metode kan betegnes som strukturalistisk. I Baldr og verdensdramaet ser Frederik Stjernfelt den som "en art tidlig strukturalisme" (Stjernfelt 1990, 9), mens Lundager Jensen og Schjødt ser "Dumézils metodiske principper [som] slet og ret strukturalistiske". I forlængelse af denne bemærkning anskues Dumézil som en af strukturalismens fædre og som en af de første, der formulerede de strukturalistiske, metodiske principper (Jensen \& Schjødt 1994, 205).

\footnotetext{
${ }^{2}$ Som (næsten) altid hos Dumézil vil man kunne henvise til flere steder, hvor et givet emne behandles. I dette tilfælde finder man én af de mest omfattende fremstillinger i Dumézil 1949.
} 
Der er betydelige forskelle mellem Dumézil og f.eks. Lévi-Strauss. Medens en væsentlig inspiration for Dumézil er den diakrone sprogvidenskab, er det for LéviStrauss primært den synkrone sprogvidenskab og her mere specifikt Saussure (formidlet via Roman Jakobson). Lévi-Strauss beskæftiger sig med almene betydningsstrukturer, som så naturligvis analyseres i deres konkrete mytologiske udformninger, mens Dumézils interesse er specifikke indoeuropæiske strukturelle fællestræk. Littleton påpeger, at Levi-Strauss og Dumézil arbejder på to forskellige abstraktionsniveauer: "For Lévi-Strauss, the level is that of the human mind itself; for Dumezil, who in no way can be classed as a dialectician, Hegelian or otherwise, the level is the more immediate one of a historically and geographically bounded set of genetically related traditions" (Littleton 1982, 268).

Dette er Lundager Jensen og Schjødt ikke ubetinget enige i (Jensen \& Schjødt 1994, 26 , særlig note 13 , og 205, inklusiv note 24 ), men jeg mener faktisk, at Littletons påvisning af forskellene er ret præcis. Tingene kompliceres imidlertid yderligere af Dumézils egne modstridende udtalelser. I indledningen til Mythe et Épopée hævder han således, at han ikke er strukturalist. Mest bombastisk er udsagnet: “... jeg er ikke, jeg var ikke, jeg har aldrig været strukturalist” (Dumézil 1995, 1086). Pointen er, understreger Dumézil i det følgende, at han ikke vil betegnes som filosofisk strukturalist. Hans metode er observation og sammenligning af det indoeuropæiske materiale, og han hævder, at han aldrig a priori forudsætter f.eks. tilstedeværelsen af en triadisk struktur (hvad der absolut kan diskuteres!). Han kan derfor sige, at han “... ikke kender til teologiske, mytologiske, institutionelle 'strukturer'” (s. 1087). Senere hævder Dumézil dog i et interview i Nouvelle Revue de Paris, at han nok alligevel er strukturalist (jf. Jensen \& Schjødt 1994, 26, note 13).

Konkluderende kan man sige, at Dumézil snarere repræsenterer en metodisk end en filosofisk strukturalisme. Den metodiske indfaldsvinkel, påvisningen af enkle strukturelle fællestræk i et omfattende materiale, har oplagte affiniteter til den lévi-strausske metode, men abstraktionsniveauet er, som Littleton påpeger, et andet, de filosofiske implikationer er ikke så omfattende, ligesom den sprogvidenskabelige inspiration er diakron snarere end synkron.

Det sidste væsentlige karakteristikon ved den dumézilske metode, som her skal fremhæves, er dens komparative karakter. Sammenligningen har været en af religionsvidenskabens primære metodiske indfaldsvinkler; det er derfor væsentligere at påpege sammenligningernes særlige karakter end udelukkende at vise, at metoden er komparativ. Frederik Stjernfelt hævder, at "sammenligningsmetoden indebærer et om end uformuleret strukturbegreb", idet den komparative metode forudsætter, at "man antager en vis 'enhed' og sluttethed i hvert af de sammenlignede myte-korpus'er" $(1990,20)$. Dette forudsætter dog igen, hvad Stjernfelt ikke påpeger, at det er et forholdsvis begrænset antal elementer eller funktioner, der sammenlignes, hvad der netop er tilfældet hos Dumézil.

Dette står i modsætning til en religionsfænomenologisk, typologisk orienteret komparativisme, som, idet den angår enkelttræk, har tendens til at blive meget om- 
fattende. ${ }^{3}$ I Les Dieux des Germains understreges forskellen af Dumézil: "Det skal slås fast: de komparative indoeuropæiske betragtninger forudsætter fælles afstamning, ikke bare universelle typologier" (Dumézil 1959a, 22). Den dumézilske komparativisme er bestemt af, at den indoeuropæiske myteforskning er udviklet i slipstrømmen på den indoeuropæiske sprogforskning, hvorfor den har overført den komparative sprogvidenskabs metode, der består i at reducere sprog til sammenlignelige enkeltelementer, til myteforskning.

\section{Indoeuropæiske semitter?}

Er trefunktionsskemaet specifikt indoeuropæisk? Hvis svaret på det spørgsmål skal være bekræftende, må to forudsætninger være opfyldt: For det første, at skemaet skal kunne genfindes $\mathrm{i}$ hele det indoeuropæiske område, og for det andet, at det ikke skal kunne findes udenfor, med mindre det i så tilfælde vil kunne forklares igennem direkte indoeuropæisk påvirkning.

Hvad den første af disse implikationer angår, er der en ofte påpeget vanskelighed ved den dumézilske teori i forhold til den græske mytologi. I en sidebemærkning i Les Dieux des Germains siger Dumézil således, at "den græske mytologi unddrager sig de indoeuropæiske kategorier” (s. 58). Det er i sig selv temmelig bemærkelsesværdigt, da den græske mytologi både er særdeles udbygget og samtidig den nok bedst undersøgte af samtlige indoeuropæiske mytologier. Der kan naturligvis i dette særdeles omfattende materiale findes mange elementer, der passer ind i trefunktionsskemaet, hvad specielt nogle af Dumézils elever, som f.eks. Jean-Pierre Vernant, har gjort opmærksom på (jf. Jensen \& Schjødt 1994, 130ff). Et eksempel på et sådant trefunktionelt element kunne være den trojanske prins Paris' valg mellem gudinderne Hera, Athene og Afrodite, som er en del af den mytologiske baggrund for den trojanske krig. Samtidig kan valget læses dumézilsk, idet gudinderne kan siges at repræsentere henholdsvis første-, anden- og tredjefunktionen. Det er imidlertid slående, at de eksempler, der kan anføres på trefunktionsskemaets optræden i græsk mytologi, har tendens til at være noget perifere (jf. Littleton 1982, 14 og Jensen \& Schjødt 1994, 130ff).

Argumentet for den græske mytologis særstilling er som oftest den græske kulturs innovative karakter, som har betydet en udvikling væk fra det oprindeligt indoeuropæiske. Når Dumézil således i indledningen til Mythe et Épopée I gør en foreløbig status over sin egen videnskabelige udvikling og fokusområder hedder det således: "Vidnesbyrdet fra grækerne, kritikere, fornyere og skabere, veg pladsen for mere konservative folk, særligt de italiske og germanske" (Dumézil 1974, 16). Lundager Jensen og Schjødt bemærker, at "Den græske kultur har allerede tidligt aflagt sig en indoeuropæisk arv, som den givetvis må have besiddet”. Dette 'givetvis' er dog i højere grad betinget af selve teorien, som kræver det, end af de empirisk konstaterbare

\footnotetext{
${ }^{3}$ Det arketypiske religionsvidenskabelige eksempel på dette er naturligvis James Frazers: The Golden Bough, hvor førsteudgaven i 1890 var på to bind, andenudgaven i 1900 på tre bind, mens den monstrøse tredjeudgave fra 1906-15 var vokset til tolv bind med en yderligere tilføjelse i 1936. Vedrørende karakteren af den dumézilske komparativisme jf. Jensen \& Schjødt 1994, 24-28.
} 
forekomster af træk af den særlige indoeuropæiske ideologi, idet der "overalt [er] tale om marginale forekomster" (Jensen \& Schjødt 1994, 130 og 132).

Det er dog betydeligt mere graverende for teoriens holdbarhed, hvis man kan konstatere distinkte indoeuropæiske karakteristika i et ikke-indoeuropæisk materiale. Atsuhiko Yoshida og Taryö Obayshi har således undersøgt den japanske mytologi og fundet klare træk af trefunktionstænkningen i den. Hvis det skal kunne forstås inden for den dumézilske teoris rammer, er den eneste forklaringsmulighed, at det drejer sig om en indoeuropæisk påvirkning; denne kan så enten forstås som en følge af egentlig militær invasion eller som en mere indirekte påvirkning ${ }^{4}$. Ideen om en påvirkning kan naturligvis ikke afvises, men under alle omstændigheder vil tilstedeværelsen af distinkte indoeuropæiske træk i det japanske mytologiske materiale sætte alvorligt spørgsmålstegn ved en af den dumézilske teoris væsentlige præmisser: Den tætte sammenhæng mellem indoeuropæiske sprog og visse strukturelle træk i tænkningen.

Et meget direkte angreb på den dumézilske teori på dette område blev foretaget af John Brough i artiklen "The tripartite ideology of the Indo-Europeans: an experiment in method", mens Dumézil svarede på kritikken i artiklen "L'idéologie tripartie des IndoEuropéens et la Bible". Udgangspunktet for John Broughs kritik er Dumézils hævdelse af, at trefunktionsskemaet ikke alene er et specifikt, men også et unikt indoeuropæisk træk:

Den sociale tredeling i gammel tid - Vedrørende dette skema er det forgæves, at man har søgt et uafhængigt gensvar i livet eller i traditionerne i de finsk-ugriske eller siberiske samfund, hos kineserne eller de bibelske hebræere, i Fønikien eller i det sumeriske eller semitiske Mesopotamien og generelt i de store kontinentale områder, der støder op til eller er gennemtrængt af Indoeuropæerne ... om det er tæt på, eller langt fra, intet ... minder om hierarkiet af tre funktionelle klasser. Der er ingen undtagelser. (Dumézil 1958, 16)

Med afsæt i denne temmelig bombastiske påstand af Dumézil, at det indoeuropæiske materiale er unikt, og at der ikke findes undtagelser, forsøger Brough at påvise trefunktionsskemaets tilstedeværelse i Det Gamle Testamente.

I 1 Mosebog velsigner Jakob sine tolv sønner, som skal blive til Israels tolv stammer. Brough forsøger at vise, at disse velsignelser falder naturligt inden for hver af de 3 funktioner med fire sønner/stammer til hver (1959, 73-74). I forlængelse af dette vil han derefter vise, at en række personer i Dommerbogen kan tolkes duméziliansk, hvorefter han gør det samme med en række personer fra Samuelsbøgerne og 1 Kongebog (s. 75ff). Hvis resultaterne af hans undersøgelser af Dommerbogen, Samuelsbøgerne og 1 Kongebog sammenskrives i et enkelt skema, vil det se således ud:

\footnotetext{
${ }^{4}$ Jf. Littleton 1982, 258-61. I Jensen \& Schjødt 1994, 199-200, er der en kort gengivelse af samme problematik, som primært synes at bygge på Littleton.
} 


\begin{tabular}{|l|l|l|}
\hline Funktion & Dommerbogen & Samuelsbøgerne og 1 Kongebog \\
\hline I. Type Mitra & Ehud & Eli \\
\hline I.Type Varuna & Deborah & Samuel \\
\hline II. Type Indra & Gideon & David (som konge) \\
\hline II. Type Vayu & Samson & Saul \\
\hline III. & [Benjamenitternes Kvinder $]$ & David (som ung) \\
\hline I.II.III. & & Salomo \\
\hline
\end{tabular}

Endelig påpeger Br0ough en række enkelte passager fra Det Gamle Testamente, som naturligt falder inden for trefunktionsskemaet (s. 81ff).

I sin kritik kan Dumézil påvise en ret høj grad af vilkårlighed i Broughs analyse. I udvælgelsen af personer fra Dommerbogen er der simpelthen en række tilfældige udeladelser (som Otniel og Jefta); der er ikke i materialet selv noget, som betinger det specifikke valg af repræsentanter for de tre funktioner med deres underkategorier (Dumézil 1959b, 102ff). At Salomo skulle opsummere alle tre funktioner er heller ikke indlysende, da der intet er i hans person af andenfunktionen (s. 105ff). På samme måde er der en høj grad af vilkårlighed og inkonsistens i eksemplerne på trefunktionelle formularer. Betyder det, at Broughs "experiment in method" skal afvises helt? Ikke nødvendigvis. Materialet fra Samuelsbøgerne og 1. Kongebog lader sig faktisk rubricere på en anden måde, der langt mere konsistent falder inden for trefunktionsskemaet, end hvad der er tilfældet hos Brough; det vil jeg forsøge at vise i det følgende. ${ }^{5}$

Et ofte forekommende tema hos Dumézil har været 'de første konger', f.eks. Roms første konger. Det må derfor være legitimt at undersøge det tilsvarende tema, Israels første konger, ud fra Dumézils teori; enhver tale om vilkårlighed i valget af personer eller tilfældig udvælgelse af det givne materiale kan her på forhånd afvises. Hvad karakteriserer så Israels første tre konger: Saul, David og Salomo, hvis de anskues trefunktionelt?

Saul er den typiske regent. Han bliver valgt efter folkets ønske, idet de ønsker "en konge over os, så vi kan få det ligesom de andre folk. Vores konge skal herske over os ..." (1 Sam 8,20-21). Saul er "et hoved højere end alt folket" (1 Sam 10,23). Samtidig er han en tragisk skikkelse, der aldrig bliver nogen succes som konge. Baggrunden for det er bl.a., at det eksplicit siges, at valget af en konge i Israel sker på trods af Guds vilje; tanken synes at være, at Gud selv ultimativt skulle have været folkets konge. Parallelt med Saul er der en anden central skikkelse, Samuel, som kan siges at repræsentere førstefunktionens magiske aspekt. Det skal retfærdigvis siges, at det juridiske aspekt ikke fremhæves tilsvarende ved Saul. Samuel er profeten, der på en særlig måde taler på Guds vegne. I introduktionen til omtalen af Samuels virke siges det således, at "hele Israel fra Dan til Be'ersheba [de geografiske yderområder i henholdsvis nord og syd] forstod, at det var betroet Samuel at være profet for Herren" (1 Sam 3,20). Han er derfor

\footnotetext{
${ }^{5}$ Der vil i de tilfælde, hvor der er sammenfald mellem Broughs og mine rubriceringer også være en vis gentagelse af hans argumenter. Når jeg derimod vil forsøge at se Salomo som en repræsentant udelukkende for tredjefunktionen, kan jeg hente argumenter for det i Dumézils kritik af Brough.
} 
også den naturlige person til på Guds vegne at salve og indsætte både Saul og hans efterfølger, David, som konger. Samtidig kan Samuel helt klart rubriceres som en førstefunktions-figur, idet han rent faktisk fungerer som folkets leder, indtil Saul indsættes som konge. Der siges således om Samuel, at han i hele sin levetid var folkets dommer, og både residerede i en bestemt geografisk lokalitet, Rama, og hvert år drog rundt i landet og dømte, hvad der er et af de traditionelle udtryk for suverænitetsfunktionen (1 Sam 7,15-17). Samuel indbefatter således både det sakrale og det juridiske aspekt, men af disse er det klart det sakrale, udtrykt ved virket som profet, der understreges kraftigst. Sauls største fejl er, at han på et tidspunkt går ind på Samuels område, den sakrale funktion, og ofrer til Gud; det bliver begyndelsen på hans deroute (1 Sam 13,7-15).

David er krigeren. Hans første heltegerning er drabet på kæmpen Goliat (1 Sam 17), som efterfølgende fører til en fremhævelse af hans krigeregenskaber på bekostning af Saul: "Da de kom tilbage, efter at David havde dræbt filisteren, gik kvinderne fra alle byer i Israel kong Saul i møde under sang og dans til pauker, glædesråb og triangler, og de dansende kvinder sang: Saul har dræbt sine tusinder, men David sine titusinder" (1 Sam 18,6-7). Som en konsekvens af dette efterstræbes David af Saul og går derfor i tjeneste hos en filisterkonge; også her fremhæves krigeraspektet (1 Sam 27). David går på egen hånd i krig med amalekitterne (1 Sam 29-30) og efter at have fået kongemagten er han i konstant krig med nabofolkene, som alle overvindes (2 Sam 5,6-12; 5,17-25; 8,1-14; 10,1-19; 12,26-31). Davids lovsang til Gud i 2 Sam 22 må også siges markant at fremhæve krigeraspektet, idet David takker Gud for, at han på en særlig måde har udrustet ham til at føre krig. Det sker i sætninger som: "Han opøver mine hænder til krig/ Og mine arme til at spænde kobberbuen" og "Du væbner mig med styrke til krig" (vers 35 og 40a); oplæringen synes at have været effektiv, idet David også kan takke Herren for de vellykkede sejre over fjenderne: "Jeg sætter efter mine fjender og udrydder dem,/ Jeg vender ikke om, før de er tilintetgjort./ Jeg tilintetgør dem og knuser dem, så de ikke kan rejse sig,/ De ligger faldne under mine fødder." (vers 38-39).

Afsluttende kan det nævnes, at 1 Krønikebogs fortælling om David fremhæver, at han ikke må bygge templet: "Gud sagde til mig: Du skal ikke bygge et hus for mit navn, for du er kriger og har udgydt blod" (1 Krøn 28,3). Konkluderende må det siges, at David meget entydigt passer ind i andenfunktionen.

Tilsvarende kan Salomo rubriceres som en tredjefunktions konge. Når der i 1 Kon 5 gives en beskrivelse af hans regeringsperiode, lyder det således:

Salomos daglige forbrug af fødevarer var tredive kor fint mel og tres kor groft mel, ti stykker fedekvæg, tyve stykker markkvæg og hundrede stykker småkvæg foruden hjorte, gazeller, rådyr og kornfedede gæs. Han herskede over hele landet vest for Eufrat, fra Tifsa til Gaza, og over alle konger i landet vest for Eufrat, og han havde fred til alle sider. Så længe Salomo levede, boede Juda og Israel trygt, enhver under sin vinstok og sit figentræ, fra Dan til Be'ersheba". (1 Kon 5,2-5) 
Regeringsperioden er altså karakteriseret ved fred, frugtbarhed og overvældende velstand, hvad der er typiske tredjefunktions kendetegn.

Når det fortælles, at Salomo bygger templet, behøver det ikke at forbinde ham i større grad med de magiske aspekter af førstefunktionen, idet beskrivelsen fremhæver rigdommen og velstanden i forbindelse med tempelbyggeriet, ligesom det fortælles i en kontekst, hvor Salomos velstand er hovedtemaet og hvor også bygningen af hans palads omtales (1 Kon 5-7). Også på et andet område forbindes Salomo med tredjefunktionen, idet han har et for gammeltestamentlige konger usædvanligt stort antal kvinder; der sættes faktisk tal på det: "Han havde syv hundrede hustruer med fyrstelig rang og tre hundrede medhustruer ..." (1 Kon 11,3). Disse hustruer viser sig så efterfølgende at blive hans problem, men det ændrer intet ved, at de primære karakteristika ved Salomo er rigdom (inklusiv rigdom på mad), visdom, fred og frugtbarhed. Han kan altså uproblematisk karakteriseres som en repræsentant for tredjefunktionen.

Konkluderende må det siges, at Israels tre første konger falder naturligt inden for de tre funktioner. I Sauls tilfælde er det svagere markeret, mens både David og Salomo er meget typiske repræsentanter for henholdsvis anden- og tredjefunktionen.

At nogle af funktionerne kan være svagere markeret, er imidlertid et træk, som man også kan finde hos Dumézil selv. I beskrivelsen af nordisk religion, som den særligt kommer til udtryk i Les Dieux des Germains, ses Odin som repræsentant for førstefunktionens magiske aspekt og Tyr for dets juridiske aspekt, Thor er andenfunktionsguden, mens tredjefunktionen dækkes af diverse Vaner: Frej, Freja, Njord. Det svage punkt i denne fremstilling er helt klart Tyr. Jensen og Schjødt konstaterer således, at der er "problemer med første funktions retsaspekt, hvis repræsentant Tyr er en noget afbleget skikkelse i det overleverede materiale" (Jensen \& Schjødt, 84). Et af problemerne er, at han oftest forbindes med krigen, hvad der naturligt ville medføre en rubricering under andenfunktionen snarere end førstefunktionen. I forhold til det argument påpeger Dumézil, at Tyr i de konkrete tekster rent faktisk ikke optræder som kriger, idet hans mest heroiske gerning er ofringen af hånden $i$ forbindelse med Fenrisulvens binding. Dumézil påpeger endvidere, at der er en toponymisk forbindelse mellem Tyr og Ting, hvad der naturligt forbinder ham med det juridiske aspekt af førstefunktionen.

Det ændrer dog ikke ved, at Tyrs rolle i den nordiske mytologi absolut ikke er central, hvad Dumézil ser som et generelt "vue pessimiste du droit" i denne. Det juridiske aspekts begrænsede plads i mytologien er ikke andet end "en nøjagtig projektion af de jordiske krigerflokke og klasser, som ikke bekymrede sig om andet end at sejre og vinde bytte " (Dumézil 1959a, 74-75). Dette må i sandhed siges at være et dystert syn på de skandinaviske samfund omkring vikingetiden, som også forekommer noget overdrevet. Krigen og kampen indtager godt nok en særdeles central plads i disse, men der var dog også en juridisk praksis udmøntet i tilstedeværelsen af f.eks. ting. Forhandlingerne på disse ting kan nok siges at være et udtryk for magtkampe, men det er vel næppe udelukkende i de skandinaviske samfund på dette tidspunkt, at man kan anlægge en sådan synsvinkel på jura og politik. Man kan derfor spørge sig, om ikke 
Dumézils vurdering af de skandinaviske samfund kan være en projektion af hans egen irritation over den mangelfulde tilstedeværelse af førstefunktionens juridiske aspekt i den nordiske mytologi?

Sammenfattende må man altså konstatere, at Israels tre første konger falder naturligt inden for hver af de tre funktioner og at der ved siden af Saul er en Samuel, som repræsenterer førstefunktionens magiske aspekt. Saul står svagt som repræsentant for det juridiske aspekt, hvad der imidlertid kan ses som helt parallelt til Tyrs "afblegede" rolle som repræsentant for det samme aspekt i nordisk religion.

Hvis dette skal forstås inden for det dumézilske paradigme, er den eneste forklaringsmulighed, at det skyldes indoeuropæisk påvirkning. Det nærmeste man kan pege på her vil så være den hittitiske kultur. Dette virker dog noget søgt og støder også på det særlige problem, at den hittitiske kultur ikke synes "at have bevaret meget af en eventuel indoeuropæisk arv" (Jensen \& Schjødt 1994, 199). Det ovenstående eksempel kan altså indikere, at trefunktionsskemaet simpelthen ikke er unikt indoeuropæisk.

\section{Konklusion}

Dumézil er en konsekvent teoretiker. Hans hovedtese er som sådan enkel, nemlig at der skulle eksistere et oprindeligt strukturelt fællestræk i indoeuropæisk tænkning, som lader sig udtrykke $\mathrm{i}$ et meget begrænset antal funktioner. Denne hovedtese har han eftersporet og forsøgt at påvise i et særdeles omfattende og forskelligartet materiale og har derved på overbevisende måde dokumenteret, at trefunktionsskemaet kan være et yderst brugbart klassifikationsprincip i forhold til det indoeuropæiske materiale.

Teorien bliver imidlertid problematisk, når den ikke kun vil beskrive karakteristiske træk i det indoeuropæiske materiale selv, man får en mere altomfattende forklaringsambition. Denne forklaringsambition udspringer af udsagnet: "Der er ingen undtagelser" (Dumézil 1958, 16). I det øjeblik Dumézil ikke kun vil udtale sig om det karakteristisk indoeuropæiske, men det unikt indoeuropæiske, er hans teori indirekte blevet et udsagn om alle eksisterende mytekomplekser, hvad der må siges at være temmelig ambitiøst! Hans påstand om, at trefunktionstænkningen alene findes i det indoeuropæiske materiale, har det også vist sig at være diskutabel.

I en problematisering af Dumézil på dette område er det naturligvis ikke nok at påvise tilfældige forekomster af magt, krig og frugtbarhed i et ikke-indoeuropæisk materiale. Det er indlysende, at man kan finde disse elementer i enhver kultur på ethvert historisk tidspunkt. Dumézils pointe var således ikke, at man kun finder suverænitet, krig og frugtbarhed i det indoeuropæiske materiale, hvad der ville være direkte tåbeligt, men netop at disse elementer i dette materiale på en unik måde samler sig i en særlig trefunktionel struktur. I Suverceniteten, kampen og frugtbarheden præciseres dette på følgende måde:

At 'suverænitet', 'krig' og 'frugtbarhed' hver for sig optræder i alle kulturer, er en trivialitet. Men det er netop ikke disse tre felter hver for sig, der er relevante, men derimod den specifikke konfiguration, som den trefunktionelle struktur danner. Der skal 
altså både foreligge en triade, og denne triade skal manifestere de tre semantiske felter, som er de tre funktioners, for at man kan tale om en trefunktionel struktur. (Jensen \& Schjødt 1994, 54)

Det i Vesteuropa mest kendte, udbredte og virkningshistorisk indflydelsesrige ikkeindoeuropæiske tekstkompleks finder man uden tvivl i Det Gamle Testamente. Vil man i dette tekstmateriale kunne se tre klart definerede semantiske felter, som falder sammen med de tre funktioner? Svaret på det spørgsmål må være bekræftende. Hvis man anlægger en dumézilsk synsvinkel på disse tekster og eftersporer et typisk dumézilsk tema, de første konger, vil man i det gammeltestamentlige materiale kunne påvise tilstedeværelsen af trefunktionstænkningen med samme sikkerhed (og usikkerhed, om man vil!), som Dumézil har gjort det i det indoeuropæiske materiale generelt. Israels tre første konger falder tydeligt inden for hver af de tre funktioner: suveræniteten, kampen og frugtbarheden. David og Salomo er entydige som henholdsvis anden- og tredjefunktionskonger, mens makkerparret Saul og Samuel kan siges at dække førstefunktionen med samme grad af tydelighed, som genfindes i Dumézils beskrivelse af Odin og Tyr som førstefunktionsguder i den nordiske mytologi.

Som en konsekvens af dette er det altså nødvendigt med en relativering af den dumézilske teoris påstand om, at trefunktionstænkningen er en enestående indoeuropæisk bevidsthedsform, idet det rent faktisk er muligt at finde triadeideologien udenfor det indoeuropæiske materiale; trefunktionstænkningen kan nok karakteriseres som typisk indoeuropæisk, men ikke som unik indoeuropæisk. Dette er tidligere blevet antydet både af trefunktionstænkningens noget perifere forekomst i græsk mytologi og dets lige så overraskende tilstedeværelse i japansk mytologi, men må siges at optræde med langt større tydelighed i det gammeltestamentlige materiale, hvad jeg mener at have påvist i ovenstående nybearbejdning af John Broughs 'metodeeksperiment'.

\author{
Litteratur \\ BROUGH, JOHN \\ 1959 "The tripartite ideology of the Indo-Europeans: an experiment in method", Bulletin of the \\ School of Oriental and African Studies, vol. 22, part 1., London, 69-85. \\ DUMÉZIL, GEORGES \\ 1941 Jupiter Mars Quirinius, Paris. \\ 1949 L'héritage indo-européenne á Rome, Paris. \\ 1958 L'idéologie tripartie des Indo-Européens, Bruxelles. \\ 1959a Les Dieux des Germains, Paris. \\ 1959b "L'idéologie tripartie des Indo-Européens et la Bible", Kratylos - Kritisches Berichts- \\ und Rezensionsorgan für Indogermanische und allgemeine Sprachwissenschaft, 4. år- \\ gang, 97-118. \\ 1970 Du Mythe au Roman - La Saga de Hadingus, Paris [1953]. \\ 1974 Mythe et Épopée I, Paris [1968]. \\ 1995 Mythe et Épopée I.II.III, Paris. \\ Jensen, Hans Jørgen Lundager \& Jens Peter Schjødt \\ 1994 Suverceniteten, kampen og frugtbarheden, Århus.
}


LitTLETON, C. SCOTT

1982 The New Comparative Mythologi, Berkeley, Los Angeles, London [1966].

NÄSSTRÖM, BRITT-MARI

2002 Forn-skandinavisk religion, Lund [2001].

STJERNFELT, FREDERIK

1990 Baldr og verdensdramaet, København.

\section{Summary}

This article is a discussion of George Dumézil's theory of a unique Indo-European ideology characterised by the tendency to think in three basic functions. Based on an earlier attempt by John Brough to critizise the theory on this point, the article presents an analysis of the 'First Kings of Israel' in the Hebrew Bible that shows their expression of the three-functionel ideology. This leads to the conclusion that while Dumézil has managed to show that the three-functional ideology is a typical Indo-European trait, it cannot be regarded as uniquely Indo-European.

Bent Bjerring-Nielsen Cand.mag.

Belgiensgade 3

2300 København S 